\title{
DAMAGE OF THE SPITTLEBUG Deois flavopicta (STAL) (HEMIPTERA: CERCOPIDAE) TO MAIZE IN INTERCROPPING SYSTEM WITH BRACHIARIA GRASS
}

IVAN CRUZ ${ }^{1}$, IVANA FERNANDES DA SILVA ${ }^{1}$, CRISTIANE SOUZA PAULA ${ }^{1}$, MARIA DE LOURDES CORREAA FIGUEIREDO ${ }^{1}$, MIGUEL MARQUES GONTIJO NETO ${ }^{1}$ and RAFAEL BRAGA DA SILVA²

${ }^{1}$ Embrapa Milho e Sorgo, Caixa Postal 151, CEP 35.701-970, Sete Lagoas,MG, Brasil, E-mail: ivancruz@cnpms.embrapa.br, ivanaf.silva@hotmail.com, cris_paula2007@yahoo.com.br, figueiredomlc@yahoo.com.br,mgontijo@cnpms.embrapa.br ${ }^{2}$ Universidade Federal de São Carlos (UFSCar), Caixa Postal 676, CEP 13.565-905, São Carlos-SP, Brasil,E-mail: rafaelentomologia@yahoo.com.br

Revista Brasileira de Milho e Sorgo, v.8, n.2, p. 117-130, 2009

\begin{abstract}
One of the possibilities of recovering degraded areas intended for cattle raising is the maize-Brachiaria spp. integration. In this system, it recovers soil fertility through the correct use of lime and adequate fertilizer replacement. The plantation of the two agricultural explorations is made simultaneously. However, the presence of some insect-pest common to both crops can reduce the efficiency of the integrated process. One of these insects is the spittlebug, Deois flavopicta (Hemiptera: Cercopidae), a sucking insect causing damage to the pastures both, through nymph and adult feeding. In maize only the adult causes damage, attacking the plant soon after its emergence. The experiment was done with the maize in the V2 phase, confining for a period of eight days a density of two adult spittlebugs/maize plant, kept alone or in association with Brachiaria species, being two susceptible (Brachiaria decumbens cv. Basilisk and B. ruziziensis cv. ruziziensis), and one resistant ( $B$. brizantha cv. marandu). In general the maize in monoculture was significantly damaged by the pest, reducing its development and showing more than $70 \%$ of yellowish leaves. The presence of Brachiaria grasses intercropped to maize plants reduced the spittlebug damage to these plants. In the presence of susceptible cultivar, such as $B$. decumbens, the damage to maize plant was lower than when together with the resistant cultivar $B$. brizantha.
\end{abstract}

Key words: maize/Brachiaria intercropping, maize pests, sucking insect, damage, insectplant interaction. 


\title{
DANOS DA CIGARRINHA DAS PASTAGENS, Deois flavopicta (STAL) (HEMIPTERA: CERCOPIDAE) NA CULTURA DO MILHO, EM PLANTIO CONSORCIADO COM BRAQUIÁRIAS
}

\begin{abstract}
RESUMO - Uma das possibilidades de recuperação de áreas degradadas destinada à pecuária é a integração milho/braquiária. Nesse sistema, recupera-se a fertilidade do solo através da utilização correta de calcário e da reposição adequada de fertilizantes. $\mathrm{O}$ plantio das duas explorações agrícolas é feito simultaneamente. No entanto, a presença da cigarrinha das pastagens, Deois flavopicta (Hemiptera: Cercopidae), inseto-praga comum aos cultivos, pode reduzir a eficiência do processo integrado. Trata-se de um inseto sugador, cujos danos às pastagens são causados tanto pelas ninfas, como pelos adultos. No milho, apenas o adulto danifica a planta logo após a sua emergência. $\mathrm{O}$ experimento foi conduzido quando o milho estava na fase V2, confinando por um período de oito dias uma densidade de duas cigarrinhas adultas/planta de milho, mantido sozinho ou em associação com três cultivares de braquiária, sendo duas suscetíveis à cigarrinha (Brachiaria decumbens $\mathrm{cv}$. Basilisk e $B$. ruziziensis cv. ruziziensis) e uma resistente (B. brizantha $\mathrm{cv}$. marandu). De maneira geral, o milho em monocultivo foi significativamente danificado pela praga, diminuindo seu desenvolvimento e apresentando amarelecimento em mais de $70 \%$ das folhas. A presença de braquiárias no plantio consorciado com o milho reduziu o nível de dano causado pela cigarrinha às plantas desta cultura. Na presença de $B$. decumbens, tida como a mais suscetível à cigarrinha, o dano nas plantas de milho foi bem menor que aquele observado no consórcio com $B$. brizantha ou B. ruziziensis, consideradas cultivares resistentes à praga.
\end{abstract}

Palavras-chave: integração milho-braquiária, pragas de milho, sugadores, danos, interação inseto-planta.

The adaptation of grasses from the genus Brachiaria (Poaceae) conditions of low fertility and high soil acidity of the Brazilian "Cerrado" biome resulted in extensive cultivation of those grasses in Brazil (Pereira et al., 2008). Among the main species cultivated, Brachiaria decumbens and $B$. ruziziensis are susceptible to spittlebug species, not only in Brazil and throughout the tropical America (EMBRAPA, 1977; Cosenza, 1981; Santos et al., 1982 Valério \& Nakano, 1988; Fontes et al., 1995, Duarte et al., 2007; ). Furthermore, B. brizantha is considered resistant to the main spittlebug species belonging to the genera Notozulia, Deois and Aeneolamia (Valério et al. 1977). In Brazil, the species Deois flavopicta (Hemiptera: Cercopidae) is the 
most frequently occurring, especially in SouthEastern and Midwestern regions (Fontes et al., 1995; Valério et al., 2000).

The adult is quite characteristic, showing black wings with two transversal yellow stripes and a yellowish ribbon-cutting longitudinal in each front wing, along with red abdomen and legs (Cruz, 2008). Females lay eggs in soil or nearby vegetation and newly-hatched nymphs establish on the basis of host plant and produces characteristic foam in which are protected (Pereira \& Pereira, 1985). Drought condition is considered unfavorable for breeding and development of D. flavopicta (Fontes et al., 1995; Pires et al., 2000a). In Brazil can occur three to five generations per year, depending on climatic conditions (Cosenza, 1989; Fontes et al., 1995). Hewitt (1988) and Nilakhe (1985) highlighted the population increases of spittlebug in Central Brazil, due to monoculture of pastures. Damage is verified not only in pasture, but also in rice, sugar cane and maize (Rosseto et al., 1978; Santos et al., 1982; Carneiro \& Cunha, 1984; Nilakhe, 1985), mainly in Goiás, Minas Gerais, Mato Grosso, Mato Grosso do Sul and São Paulo states. Bernardo et al. (2003) highlighted the importance of D. flavopicta compared to other species associated with host grasses. Usually, spittlebug population in pasture are low during dry season (winter) and increases with the rainy season (summer) by the time maize crop is sown. Migration of adults from pasture to maize can cause severe damage to maize seedling.
The main Brachiaria cultivars used in the system integrated with maize are Brachiaria ruziziensis originating from Africa (Burundi, Rwanda, and Eastern Zaire), a decumbent perennial plant with rhizomes, forming dense foliage, and susceptible to spittlebug (Cook et al., 2005).

Brachiaria brizantha, also originated from Africa. With the exception of northern Brazil, this is the best alternative spittlebug resistant grass forage. In those areas where extensive monocultures have been established with this grass there have been registered high levels and damage caused by a species of spittlebug typical of sugar cane, belonging to genus Mahanarva (Hemiptera: Cercopidae). It is believed that over the past 20 years, since the release of this grass, the constant use of "marandú" cultivar was responsible for the increase of Mahanarva genus and decrease of typical pasture spittlebugs species. Mahanarva species are larger and with more damage capacity (Valério, 2006).

Brachiaria decumbens is a perennial grass with a decumbent growth habit, susceptible to spittlebug (Cook et al., 2005).

In maize crop there is little biological information about spittlebugs. It is known, however, that, unlike pastures where both nymphs and adults cause damage, in monoculture of maize attack is only by adults (Santos et al., 1982). Spittlebugs are sap sucking insects causing subsequent yellowish, dryness and death of both maize and pasture plant, especially when the attack is in seedlings. In 
pasture, beyond quantitative damage, spittlebug reduces levels of crude protein, fat and essential minerals, increases the dry matter and decreases the grass palatability (Pereira et al., 1982; Hewitt, 1988; Valério \& Nakano, 1988; Tônus, 1999). It is great the importance of the presence of insect pest species in the initial development stage of maize plant due to the fact of maximum number of grains or production potential of maize be defined in the V 3 stadium (Magalhães et. al., 2002), that is, coincides with the incidence of those pests. Quantitative studies on impacts caused by spittlebug in association with different forage crops have demonstrated a significant negative effect on both yield and quality of food in Brazilian tropical conditions (Valério \& Nakano, 1987, 1988, 1989). Losses of up to 34 million dollars have been reported to the conditions of Colombia (Holmann \& Peck, 2002). Few quantitative data are reported on the spittlebugs attack on maize crop. However, when pest outbreaks occur, the yields are very low. These outbreaks in maize do not have been constant when maize is grown in summer season. However, in the second season the presence of the pest is more common (Cruz, 2008). The great concern, however, is for the intercropping system, i.e. the simultaneous presence of maize and brachiaria. As emphasized by Sujii et al. (2001) the occurrence of pest has been related to abiotic factors such as precipitation, temperature and evapotranspiration and absence of natural enemies. However, quantitative and qualitative availability of the host can also play a key role in population dynamics of pest affecting directly both nymphs and adults (Pires et al., 2000b). Therefore, in the maize/pasture production system there is enough food availability to provide a continuous breading of the insect pest which can then choose between one and other food source.

The objective of this work was to assess if maize plants intercropped with brachiaria grass can be less damaged by the spittlebug than maize crop in monoculture.

\section{Material and Methods}

This work was done in the experimental station of EMBRAPA Maize and Sorghum Research Center, located in the city of Sete Lagoas, Minas Gerais State, Brazil. Plant damage caused by the spittlebug $D$. flavopicta was assessed on maize plant when cultivated alone or intercropped with one of the three Brachiaria species selected: B. ruziziensis (cultivar "ruziziensis", susceptible), $B$. decumbens (cultivar "basilik", susceptible) and B. brizantha, (cultivar "marandú", high resistance).

The experiment was conducted inside a greenhouse with average temperature of $25 \pm 5^{\circ} \mathrm{C}$. The treatments were arranged in a 4 x 2 factorial scheme, in a randomized complete block design with seven replications. Treatments were composed by maize plants cultivated alone or together with one of three types of Brachiaria, infested or non-infested by spittlebug. The brachiaria cultivars were sown (four gram/pot) 
individually in plastic pots with a capacity of 20 liters, containing $15 \mathrm{~kg}$ of soil mixed with $10 \mathrm{~g}$ of fertilizer NPK 8-28-16 Zn. Four seeds/pot of the maize hybrid BRS 1035 was sown six days after the brachiaria. The number of maize plant was thinned leaving only two plants per pot, just after plant emergence.

Spittlebugs were obtained from natural brachiaria fields and infestation on experiment began when the maize plants were at V2 stage, according to the Magalhães et al. (2002). A cage $20 \mathrm{~cm}$ in diameter by $34 \mathrm{~cm}$ high, made of wire and covered by a fine cloth was used to confine the spittlebugs on plants. The density of two spittlebugs per maize plant was released for infestation (Santos et al., 1982). Dead insects were replaced daily. Pots containing plants without infestation were left as blank treatments. The insects were kept on the plants during eight consecutive days.

Immediately prior to the infestation, maize plant measurements were carried out, from the base of the plant until the longest leaf sheet. Two other measurements were made, six and eight days after the infestation, to compare the effect of the continuous presence of insect pest feeding on plants. In these two measurement occasions, it was also evaluated the symptom of damage caused by the insect pest in terms of discoloration of the attacked plant (yellowish), assigned individually to each plant maize through a visual scale from 0 to 10 , with 0 meaning plant without apparent damage and 10 for plant displaying more than $90 \%$ of yellow portions of the plant or even, a dead plant. Intermediary damage classification amounted to each $10 \%$ of yellowish interval. Relative growth of maize plant in the various treatments was calculated based on the average length of the plants in each treatment in relation to the average length of maize plants without spittlebug infestation and without the presence of brachiaria ("natural growth"). After the last evaluation all maize plants were cut off at the base to obtain individual fresh weight. Dry weight was obtained after drying the plants under $65^{\circ} \mathrm{C}$ for four consecutive days. The data were submited to analysis of variance and mean comparison by Tukey test at 5\% significance.

\section{Results and Discussion}

\section{Maize development}

Considering all treatments, maize plant prior to the infestation averaged $14.18 \mathrm{~cm}$ in length. However, when maize was sown in conjunction with $B$. decumbens or $B$. ruziziensis, the plants were significantly more developed than those sown together with the $B$. brizantha or sown alone in vessels (Table 1). In other words, maize plants were about two centimeters taller. The presence of $B$. brizantha did not affect maize plant development. However, apparently, maize growth was stimulated in the presence of $B$. decumbens or B. ruziziensis.

At the first evaluation of plant height, held six days after the infestation with spittlebug, there were significant differences between 
infested and non-infested plants, except for the treatment where maize was together with B. decumbens (Table 1). Considering only non infested plots, there was no significant difference in maize plant development among treatments, indicating a leveling off compared to the previous assessment. However, under infested plots, maize plant without the presence of brachiaria grass was significantly smaller than maize plants in the other treatments. The highest development of the maize plant was verified on the plots where maize was planted along with $B$. decumbens or $B$. ruziziensis. Maize plants in these plots were $38.1 \mathrm{~cm}$ tall. This mean was significantly superior to that mean obtained from plots where maize was along with the $B$. brizantha $(30.54 \mathrm{~cm})$ which in turn was also superior to the mean obtained from plots where the maize stayed without the presence of Brachiaria $(22.25 \mathrm{~cm})$.

TABLE 1. Maize plant length (mean \pm standard error) with or without the presence of Brachiaria spp. and the spittlebug, Deois flavopicta (Hemiptera: Cercopidae).

\begin{tabular}{|c|c|c|c|c|c|}
\hline \multirow{4}{*}{ Treatments } & \multicolumn{5}{|c|}{ Maize plant length $(\mathrm{cm})^{1}$} \\
\hline & \multicolumn{5}{|c|}{ Evaluation } \\
\hline & \multirow{2}{*}{$\begin{array}{c}\text { Before } \\
\text { infestation }\end{array}$} & \multicolumn{2}{|c|}{$6 \mathrm{DAI}^{2}$} & \multicolumn{2}{|c|}{8 DAI } \\
\hline & & $\mathbf{I}^{3}$ & NI & I & NI \\
\hline Maize & $13.05 \pm 0.6 \mathrm{~B}$ & $22.25 \pm 4.3 \mathrm{Cb}$ & $44.75 \pm 2.5 \mathrm{Aa}$ & $23.46 \pm 4.8 \mathrm{Cb}$ & $54.68 \pm 2.1 \mathrm{Aa}$ \\
\hline $\begin{array}{l}\text { Maize }+B . \\
\text { brizantha } \mathrm{cv} \\
\text { marandú }\end{array}$ & $13.39 \pm 1.8 \mathrm{~B}$ & $30.54 \pm 5.5 \mathrm{Bb}$ & $40.27 \pm 7.6 \mathrm{Aa}$ & $32.64 \pm 6.4 \mathrm{Bb}$ & $52.46 \pm 3.4 \mathrm{Aa}$ \\
\hline $\begin{array}{l}\text { Maize }+B \text {. } \\
\text { decumbens cv } \\
\text { basilik }\end{array}$ & $14.81 \pm 1.6 \mathrm{~A}$ & $39.82 \pm 5.2 \mathrm{Aa}$ & $40.25 \pm 2.5 \mathrm{Aa}$ & $43.94 \pm 6.9 \mathrm{Aa}$ & $51.54 \pm 4.4 \mathrm{Aa}$ \\
\hline $\begin{array}{l}\text { Maize }+B . \\
\text { ruziziensis cv } \\
\text { ruziziensis }\end{array}$ & $15.44 \pm 1.0 \mathrm{~A}$ & $36.46 \pm 5.9 \mathrm{Ab}$ & $45.07 \pm 2.5 \mathrm{Aa}$ & $44.79 \pm 5.0 \mathrm{Aa}$ & $49.86 \pm 8.1 \mathrm{Aa}$ \\
\hline Mean & $\mathbf{1 4 . 1 8} \pm 0.96$ & $32.27 \pm 5.8 \mathbf{b}$ & $\mathbf{4 2 . 5 9} \pm 2.3 \mathbf{a}$ & $36.21 \pm 8.2 \mathbf{b}$ & $\mathbf{5 2 . 1 3} \pm 1.4 \mathbf{a}$ \\
\hline $\begin{array}{l}\text { Relative } \\
\text { Index }\end{array}$ & & 76 & 100 & 69 & 100 \\
\hline $\begin{array}{l}{ }^{1} \text { Means followed } \\
\text { different accordin } \\
{ }^{2} \text { DAI, days after } \\
{ }^{3} \text { I, Infested; NI, N }\end{array}$ & $\begin{array}{l}\mathrm{d} \text { by same capital lett } \\
\text { ing to Tukey test }(5 \% \\
\mathrm{r} \text { infestation } \\
\text { Non infested }\end{array}$ & $\begin{array}{l}\text { er on column and sm } \\
\text { ). }\end{array}$ & nall letter on line, in & each evaluation perio & d, are not significar \\
\hline
\end{tabular}

Revista Brasileira de Milho e Sorgo, v.8, n.2, p. 117-130, 2009

Versão impressa ISSN 1676-689X / Versão on line ISSN 1980-6477 - http://www.abms.org.br 
Similar situation was verified in the evaluation carried out eight days after the infestation. There was no significant difference in maize development on plots without spittlebug, for all treatments. Again, on infested plots the maize plant development was lower when maize was planted without brachiaria grasses.

The average maize plant height, on spittlebug infested plots where maize was alone or together with $B$. brizantha was significantly lower than the mean size of maize plant on the similar plots but without infestation. When maize was together with $B$. decumbens or $B$. ruziziensis there was no significant difference on maize plant growth even with or without spittlebug infestation.

Six days after infestation, in the absence of brachiaria, maize presented growth 50\% below the normal growth. Therefore, such reduction was due solely to the spittlebug feeding. The reduction in the maize plant growth was significantly smaller when associated with brachiaria, especially in the presence of $B$. decumbens. In the presence of this brachiaria species the decrease in maize plant length under spittlebug's attack was $10 \%$ on average, suggesting that the spittlebug have preferred more brachiaria than maize. Conversely, when maize was together with $B$. brizantha, a resistant cultivar, the spittlebug preferred the maize, and the decrease in average length of this plant was $30 \%$. Reduction of $19 \%$ was verified when maize was associated with B. ruziziensis. Therefore, when the spittlebug had no brachiaria cultivars as alternative food source, the damage to maize was higher. Also, apparently there was no effect of spittlebug on the development of maize plant in the presence of the susceptible cultivar $B$. decumbens. This cultivar indeed was preferred by the spittlebug as food source. Without insect infestation, maize plant did not reduce length in the presence of B. ruziziensis. However, there was a $10 \%$ length reduction when maize plant was associated with $B$. brizantha or $B$. decumbens (Table 1).

Evaluations made eight days after spittlebug infestation indicated reduction of $40 \%$ in maize development (plant length) when maize was together with $B$. brizantha and $20 \%$ when together with $B$. decumbens or $B$. ruziziensis. The maize development suffered a growth reduction of $52 \%$ when maize where the only food source to the spittlebug. Without pest infestation the maize growth was not affected by the presence of brachiaria grasses.

\section{Maize plant discoloration (yellowish)}

There were significant differences in maize plant discoloration among treatments on spittlebug infested plots (Table 2). In the first evaluation, average damage scale assigned to maize plants ranged from 2.9 to 5.1. Maize plants suffered the highest damage when the spittlebug had no food choice, except maize. In the other hand, the lowest damage on maize plant was verified when the maize plant was together with the spittlebug susceptible brachiaria cultivar, $B$. decumbens or B. ruziziensis (intermediary 


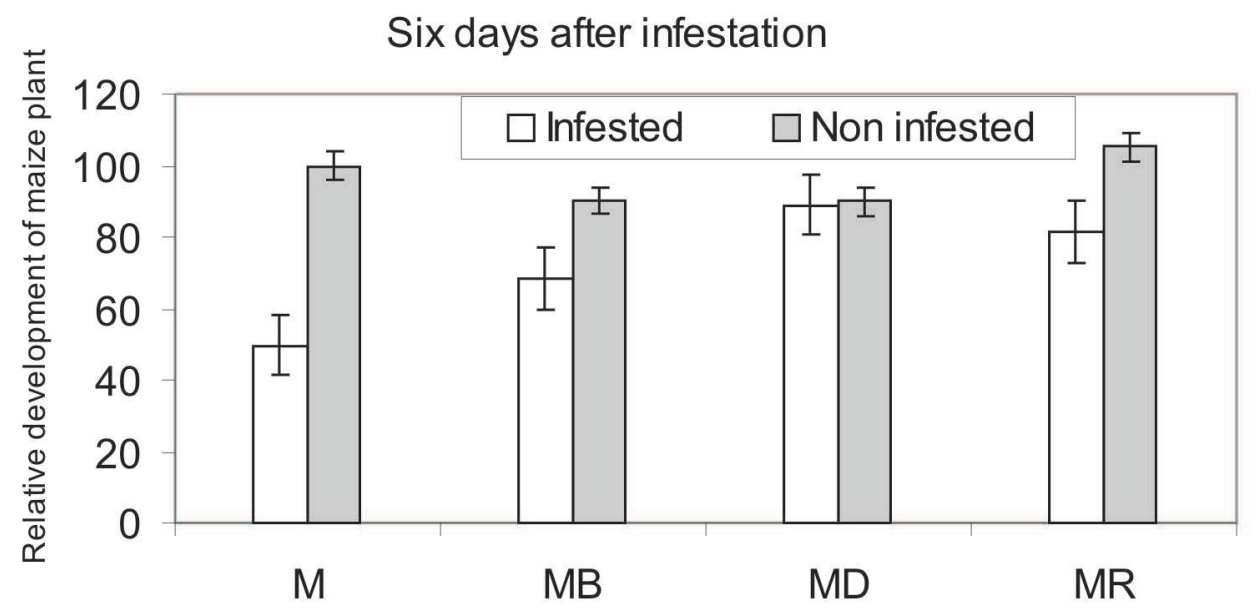

Eight days after infestation

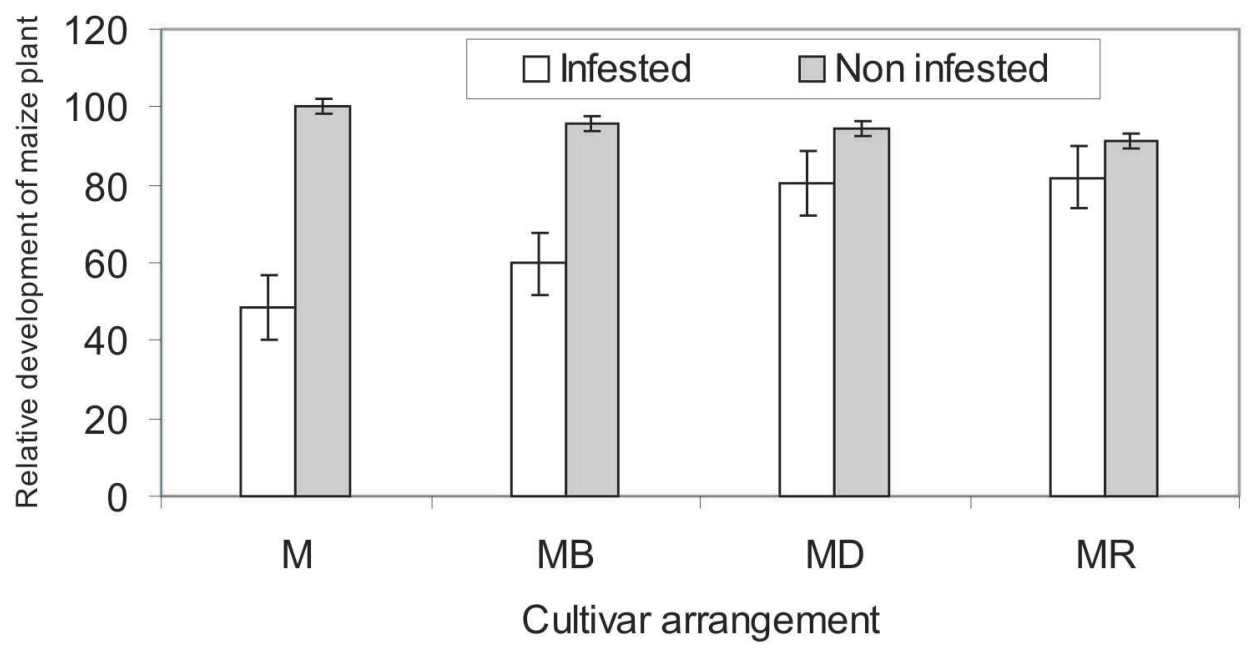

FIGURE 1. Maize plant length, with or without the presence of brachiaria grass (maize alone, M; maize in the presence of $B$. brizantha, MB; maize in the presence of $B$. decumbens, MD and maize in the presence of B. ruziziensis, MR), and the spittlebug, Deois flavopicta, six and eight days after infestation, based on maize check plot development (maize alone and without insect infestation). 
TABLE 2. Damage (plant yellowish) (mean \pm standard error) and maize plant weight (mean \pm standard error), with or without the presence of Brachiaria and spittlebug, Deois flavopicta (Hemiptera: Cercopidae).

\begin{tabular}{|c|c|c|c|c|c|c|}
\hline \multirow{3}{*}{ Treatments } & \multirow{2}{*}{\multicolumn{2}{|c|}{$\begin{array}{c}\text { Plant yellowish } \\
\text { Evaluation (DAI) }\end{array}$}} & \multicolumn{4}{|c|}{ Mean weight (g) of above ground / plant $^{1}$} \\
\hline & & & \multicolumn{2}{|c|}{ Fresh } & \multicolumn{2}{|c|}{ Dry } \\
\hline & 6 & 8 & $\mathbf{I}^{3}$ & NI & $\mathbf{I}$ & NI \\
\hline Maize & $5.6 \pm 2.2 \mathrm{~A}$ & $7.6 \pm 1.6 \mathrm{~A}$ & $1.42 \pm 0.8 \mathrm{Bb}$ & $9.84 \pm 0.9 \mathrm{Aa}$ & $0.20 \pm 0.0 \mathrm{Bb}$ & $0.68 \pm 0.1 \mathrm{Aa}$ \\
\hline $\begin{array}{l}\text { Maize }+B \text {. brizantha } \\
\text { cv marandú }\end{array}$ & $5.1 \pm 2.2 \mathrm{~A}$ & $6.4 \pm 2.4 \mathrm{~A}$ & $3.32 \pm 1.8 \mathrm{ABb}$ & $7.96 \pm 1.6 \mathrm{Aba}$ & $0.33 \pm 0.1 \mathrm{ABb}$ & $\begin{array}{l}0.57 \pm 0.1 \\
\mathrm{ABa}\end{array}$ \\
\hline $\begin{array}{l}\text { Maize }+B \text {. } \\
\text { decumbens cv basilik }\end{array}$ & $2.9 \pm 1.7 \mathrm{~B}$ & $5.5 \pm 2.1 \mathrm{AB}$ & $4.56 \pm 1.4 \mathrm{Ab}$ & $6.38 \pm 2.0 \mathrm{Ba}$ & $0.40 \pm 0.1 \mathrm{Aa}$ & $0.46 \pm 0.1 \mathrm{Ba}$ \\
\hline $\begin{array}{l}\text { Maize }+ \text { B. ruziziensis } \\
\mathrm{cv} \text { ruziziensis }\end{array}$ & $3.4 \pm 1.9 \mathrm{AB}$ & $4.0 \pm 2.5 \mathrm{~B}$ & $3.46 \pm 1.4 \mathrm{ABb}$ & $5.71 \pm 0.6 \mathrm{Ba}$ & $0.32 \pm 0.1 \mathrm{ABa}$ & $0.43 \pm 0.0 \mathrm{Ba}$ \\
\hline Mean & $4.20 \pm 1.1 \mathrm{~b}$ & $5.80 \pm 1.1 \mathrm{a}$ & $3.19 \pm 0.3 \mathrm{~b}$ & $7.47 \pm 0.3 \mathrm{a}$ & $0.31 \pm 0,0 \mathrm{~b}$ & $0.54 \pm 0.0 \mathrm{a}$ \\
\hline
\end{tabular}

${ }^{1}$ Means followed by same capital letter on column and small letter on line, in each evaluation are not significantly different according to Tukey test (5\%).

${ }^{2} \mathrm{DAI}$, days after infestation

${ }^{3}$ I, Infested; NI, Non infested

resistant cultivar). Maize plant was equally damaged by the spittlebug when planted alone or in the presence of the spittlebug resistant cultivar $B$. brizantha suggesting that in simultaneous field cultivation of both crops the damage to maize could be an adverse limiting factor to grain yield.

In the second evaluation, eight days after spittlebug infestation in general, the damage to maize plant was high, even on those plots where maize was planted together with susceptible brachiaria cultivar $B$. decumbens. The damage rate was 5.5. This mean was not significantly different from those verified on maize plant alone (7.6) or together with B. brizantha (6.1).

Maize plants submitted to spittlebug infestation presented discoloration above $40 \%$ in the first evaluation and above $50 \%$ in the second, during a relative short period of time under a fix spittlebug infestation density of two insect adult/maize plant. That is, insect feeding during six or eight days is enough to cause a high level of discoloration on maize plant, independent on being alone or together with a brachiaria cultivar.

\section{Average maize plant weight}

A significant interaction was found between maize planting system and spittlebug infestation ( $\mathrm{p} \leq 0.01$ ) after eight days of infestation by spittlebug D. flavopicta. On the infested plots there was a trent to a greater fresh weight of maize plants when they were in the presence of brachiaria (Table 2). In absolute terms, the average 
fresh weight of maize sown together with $B$. decumbens, which is susceptible to spittlebug, was the largest ( $4.56 \mathrm{~g} /$ plant). This weight was significantly greater than that obtained from maize plots without the presence of brachiaria grass $(1.42 \mathrm{~g} /$ plant $)$. The fresh weight of maize in the presence of $B$. decumbens and under infestation of spittlebug was 3.2 times greater than the weight obtained from infested maize plants without brachiaria. In the presence of $B$. brizantha or B. ruziziensis, the fresh weight of the maize plant also was between 2.4 and 2.6 times. The fresh weight when maize plants were not subject to the spittlebug infestation was influenced by the presence of $B$. decumbens and B. ruziziensis (Table 2). Maize plants without the presence of brachiaria grass weighted $9.84 \mathrm{~g}$. This mean was significantly similar to that obtained from maize plant in the presence of $B$. brizantha (7.96 g). Average fresh weight of maize plant when together with $B$. decumbens or $B$. ruziziensis was, respectively, 6.38 and $5.71 \mathrm{~g} /$ plant.

Maize plant alone or together with a brachiaria cultivar and infested by spittlebugs, had, on average, the dry weight significantly lower than plant without infestation, around $41 \%$ less. On non infested plots, maize sown alone or together with $B$. brizantha presented significantly higher dry weight than plants on similar plots but without infestation. On the other hand, the dry weight of maize plant was not different from the dry weight obtained from plots where maize was together with $B$. decumbens or B. ruziziensis (Table 2).
Considering the overall results, in terms of plant development and plant weight on plots without spittlebug infestation, $B$. decumbens and $B$. ruziziensis had more influence on maize performance than $B$. brizantha. Under spittlebug infestation, all brachiaria reduced the damage on maize plant indicating the preference of the insect pest to this host. This fact becomes more apparent when evaluating the effect of the presence or absence of infestation separately in each consortium or maize alone. On the plots where maize was together with $B$. ruziziensis or with $B$. decumbens, both more susceptible to spittlebug than B. brizantha, there was no significant difference on the maize development (Table 1) or dry weight production (Table 2). On plots with maize alone or plots with maize and spittlebug resistant cultivar $B$. brizantha, there was a significant reduction in the development and in the weight of maize plant due to spittlebug infestation.

It is well known that the biotic limitation on brachiaria grass pasture productivity in Neotropical region are the many native genera and species of grassland spittlebugs (Hemiptera: Cercopidae) (Valério et al., 1996; Holmann \& Peck, 2002), although, D. flavopicta seems to be the predominant species as reported by Pires et al (2000c) and Bernardo et al. (2003). Among most common brachiaria grass, "Basilisk" signal grass and common commercial ruzigrass are particularly susceptible (Miles et al, 2006), and 'Marandu' palisade grass is resistant to spittlebugs (Nunes et al., 1984). Marandu is 
now extensively sown, though its adaptation does not extend to the very low fertility soils where cv. Basilisk is so well adapted. Ruzigrass, though of high nutritional quality (Valle et al., 1988; Lascano \& Euclides, 1996), is only a minor commercial species in tropical America owing to its poor adaptation to low fertility soils and particularly to its extreme susceptibility to spittlebugs (Keller-Grein et al., 1996).

Although spittlebugs are key pest of pasture, it is not uncommon a sharp population reduction of adults in this crop in a short period of time, sometimes in a 24-hours period (Nilakhe \& Buainain, 1988) and peaks on maize and rice crops (Santos et al., 1982; Carneiro \& Cunha, 1984; Nilakhe et al., 1984), where only adults occur. This fact suggest that migratory movement of adult population is the responsible for initial infestation in other crops (Nilakhe \& Buainain, 1988; Sujii, 1994; Fontes et al., 1995). Sujii et al (2000) pointed out that spittlebugs moved mainly by short, low jumping flights (bellow $1 \mathrm{~m}$ ) suggesting that maize crop near pasture could suffered more injury than crops away.

In general, information about spittlebugs is concern only to pasture crop system, where each cultivar is alone in the area. However, in intercropping system including maize and brachiaria the insect can stay in the area where there is enough food sources. As can be seen in Table 2, damage to maize plant were high after a 8-day feeding period under a density of two spittlebug adults/maize plant. When the insect had no food choice, except for maize, or when it could choose between maize and a resistant cultivar of Brachiaria (B. brizantha) the damage to maize plants was lower, but not to much. That is, the insect density was enough to cause a severe damage to both food sources.

\section{Conclusion}

The presence of Brachiaria grass simultaneously sown with maize reduces the damage caused by spittlebug, Deois flavopicta, on maize. The largest reduction on damage was obtained when maize was together with the most susceptible brachiaria cultivar.

In field conditions, the presence of susceptible brachiaria grass can favor the increase of spittlebug population to a density able to cause economic injury in both hosts, indicating the need for research in that condition.

\section{Reference cited}

BERNARDO, E. R. A.; ROCHA, V. F.; PUGA, O.; SILVA, R. A. Espécies de cigarrinhas-daspastagens (Hemiptera: Cercopidae) no meionorte do Mato Grosso. Ciência Rural, Santa Maria, v. 22, n. 2, p. 369-371, 2003.

CARNEIRO, M. F.; CUNHA, H. F. da. Avaliação de danos e controle da cigarrinhadas-pastagens (Deois flavopicta) na cultura do milho. Goiânia: EMGOPA, 1984. 14 p. (EMGOPA. Boletim de pesquisa, 7).

COOK, B. G.; PENGELLY, B. C.; BROWN, S. D.; DONNELLY, J. L.; EAGLES, D. A.; FRANCO, M. A.; HANSON, J.; MULLEN, 
B. F.; PARTRIDGE, I. J.; PETERS, M.; SCHULTZE-KRAFT, R. Tropical Forages: an interactive selection tool. Brisbane: CSIRO: DPI\&F(Q1d): CIAT: ILRI, 2005. CDROM

COSENZA, G. W. Resistência de gramíneas forrageiras à cigarrinha-das-pastagens Deois flavopicta (Stal., 1854). Planaltina: EMBRAPACPAC, 1981.16 p. (EMBRAPA-CPAC. Boletim de pesquisa, 7).

COSENZA, G. W. Biologia e ecologia de pragas das pastagens. In: SIMPÓSIO SOBRE ECOSSISTEMA DE PASTAGENS, 1989, Jaboticabal. Anais... Jaboticabal: FUNEP, 1989. p. 87-96.

DUARTE, M. de L. R.; ALBUQUERQUE, F. C.; SANHUEZA, R. M. V.; VERZIGNASSI, J. R.; KONDO, N. Etiologia da podridão do coleto de Brachiaria brizantha em pastagens da Amazônia. Fitopatologia Brasileira, Brasília, DF, v. 32, n. 3, p. 261-265, 2007.

EMBRAPA. Programa nacional de controle às cigarrinhas-das-pastagens. Brasília, DF: EMBRAPA, 1977. 17 p.

FONTES, E. G.; PIRES, C. S. S.; SUJII, E. R. Mixed risk spreading strategies and the population dynamics of a Brazilian pasture pest, Deois flavopicta (Homoptera: Cercopidae). Journal of Economic Entomology, College Park, v. 88, n. 5, p. 1256-1262, 1995.

HEWITT, G. B. Grazing management as a means of regulating spittlebug (Homoptera: Cercopidae) numbers in Central Brazil. Pesquisa Agropecuária Brasileira, Brasília, DF, v. 23, n. 7, p. 697-707, 1988.
HOLMANN, F.; PECK, D. C. Economic damage of grassland spittlebugs (Homoptera: Cercopidae) in Colombia: a first approximation of impact o animal production in Brachiaria decumbens. Neotropical Entomology, Londrina, v. 31, p. 275-284. 2002.

KELLER-GREIN， G.; MASS， B. L.; HANSON, J. Natural variation in Brachiaria and existing germplasm collections. In: MILES, J. W.; MAASS, B. L.; VALLE, C. B. do (Ed.). Brachiaria: biology, agronomy and improvement. Cali: CIAT; Campo Grande: EMBRAPA-CNPGC, 1996. p. 16-42.

LASCANO, C. E.; EUCLIDES, V. P .B. Nutritional quality and animal production of Brachiaria pastures. In: MILES, J. W.; MAASS, B. L.; VALLE, C. B. do (Ed.). Brachiaria: biology, agronomy and improvement. Cali: CIAT; Campo Grande: EMBRAPA-CNPGC, 1996. p. 106-123

MAGAlHÃES，P. C.; DURÃES，F. O. M.; CARNEIRO, N. P.; PAIVA, E. Fisiologia do milho. Sete Lagoas: EMBRAPA-CNPMS, 2002. 23 p. (EMBRAPA-CNPMS. Circular técnica, 22).

MILES, J. W.; CARDONA, C.; SOTELO, G. Recurrent selection in a synthetic brachiaria grass population improves resistance to three spittlebug species. Crop Sciences, Madison, v. 46, p.1088-1093, 2006.

NILAKHE, S. S. Ecological observations on spittlebug with emphasis on their occurrence in rice. Pesquisa Agropecuária Brasileira, Brasília, DF, v. 20, n. 4, p. 407-414, 1985.

NUNES, S. G.; BOOCK, A.; PENTEADO, M. I. de O.; GOMES, D. T. Brachiaria brizantha 
cv. Marandu. Campo Grande: EMBRAPACNPGC, 1985. 31 p. (EMBRAPA-CNPGC. Documentos, 21).

PEREIRA, M. F. A.; BENEDETTI, R. A. L.; ALMEIDA, J. E. M. Eficiência de Metarhizium anisopliae (Metsch) Sorokin no controle de Deois flavopicta (Stal., 1854), em pastagem de capim-braquiária (Brachiaria decumbens). Arquivos do Instituto Biológico, São Paulo, v. 75, n. 4, p. 465-469, 2008.

PEREIRA, J. C. R.; NAZAR, R.A.;ARMOUND, W. B. Interrelacionamento de macro e micronutrientes com diferentes densidades de cigarrinhas-das-pastagens. Belo Horizonte: Divisão de Defesa Sanitária Vegetal, 1982. 15 p.

\section{PEREIRA, J. R.; PEREIRA, J. C. R. Cigarrinha} das pastagens: importância e métodos de controle para a Zona da Mata de Minas Gerais. Coronel Pacheco: EMBRAPA-CNPGL, 1985. 23 p. (EMBRAPA-CNPGL. Circular técnica, 25).

PIRES, C. S. S.; SUJII, E. R.; FONTES, E. M. G.; TAUBER, C. A.; TAUBER, M. J. Dryseason embryonic dormancy in Deois flavopicta (Homoptera: Cercopidae): Roles of temperature and moisture in nature. Enviromental Entomology, College Park, v. 29, n. 4, p.714720, 2000a.

PIRES, C. S. S.; PRICE, P. W.; FONTES, E. M. G. Preference performance linkage in the neotropical spittlebug Deois flavopicta, and its relation to the phylogenetic constraints hypothesis. Ecological Entomology, London, v. 25, p.71-80, 2000b.

PIRES, C. S. S.; PRICE, P. W.; OLIVEIRA, R. C. de. Distribution of the spittlebug Deois flavopicta Stal (Homoptera: Cercopidae) on wild and cultivated host species. Anais da Sociedade Entomológica do Brasil, Londrina, v. 29, n. 3, p. 401-412, 2000c.

ROSSETO, C.J.; MARTINS, J. F. S.; SCHMIDT, N. C.; AZZINI, L. E.. Danos causados, por cigarrinhas de pastagens (Deois flavopicta e D. schach) em arroz. Bragantia, Campinas, v. 37, n. 1, p. 35-37, 1978.

SANTOS, P. J.; CRUZ, I.; BOTELHO, W. Avaliação de dano e controle das cigarrinhasdas-pastagens em plantas de milho com diferentes idades. Sete Lagoas : EMBRAPACNPMS, 1982. 9 p. (EMBRAPA-CNPMS. Pesquisa em andamento, 2).

SUJII, E. R.; GARCIA, M.A.; FONTES, E.M.G.; O'NEIL, R.J. Pachycondyla obscuricornis as natural enemy of the spittlebug Deois flavopicta. Pesquisa Agropecuária Brasileira, Brasilia, v. 39, n. 6, p.607-609, 2004.

SUJII, E. R.; PIRES, C. S. S.; FONTES, E. M. G.; GARCIA, M. A. Effect of host plant on the fecundity of spittlebug Deois flavopicta Stal (Homoptera: Cercopidae): implications on population dynamics. Neotropical Entomology, Londrina, v. 30, n. 4, p. 547-552, 2001.

SUJII, E. R.; GARCIA, M. A; FONTES, E. M.G. Movimentos de migração e dispersão de adultos da cigarrinha-das-pastagens. Pesquisa Agropecuária Brasileira, Brasília, DF, v. 35, n. 3, p. 471-480, 2000.

TÔNUS, M. Manejo integrado controla cigarrinhas em pastagens. Balde Branco, São Paulo, n. 421, p.38-45, 1999.

VALÉRIO, J. R. Considerações sobre a morte de pastagens de Brachiaria brizantha cv. Marandu em alguns Estados do Centro e Norte do país 
- Enfoque entomológico. In: BARBOSA, R. A. (Ed.). Morte de pastos de braquiárias. Campo Gande: Embrapa Gado de Corte, 2006. p. 13550 .

VALÉRIO, J. R.; JELLER, H.; PEIXER, J. Seleção de Introduções do Gênero Brachiaria (Griseb) Resistentes à Cigarrinha Zulia entreriana (Berg) (Homoptera: Cercopidae). Anais da Sociedade Entomológica do Brasil, Londrina, v. 26, n. 2, p. 383-387, 1997.

VALÉRIO, J. R.; NAKANO, O. Dano causado por adultos da cigarrinha Zulia entreriana (Berg, 1879) (Homoptera: Cercopidae) na produção de raízes de Brachiaria decumbens Stapf. Anais da Sociedade Entomológica do Brasil, Londrina, v. 16, p. 205-221, 1987.

VALÉRIO, J. R.; LAPOINTE, S. L.; KELEMU, S.; FERNANDES, C. D.; MORALES, F. J. Pests and diseases of Brachiaria species. In:
MILES, J. W.; MAASS, B. L.; VALLE, C. B. do (Ed.). Brachiaria: biology, agronomy and improvement. Cali: CIAT; Campo Grande: EMBRAPA-CNPGC, 1996. p. 87-105.

VALÉRIO, J. R.; NAKANO, O. Influência do adulto de Zulia entreriana (Berg, 1879) (Homoptera: Cercopidae) na produção e qualidade de Brachiaria decumbens. Pesquisa Agropecuária Brasileira, DF, v. 23, n. 5, p. 447-453, 1988.

VALÉRIO, J. R.; SOUZA, O. C. de; VIEIRA, J. M.; CORREAA, E. S. Diagnóstico de morte de pastagens nas regiões, central e norte do Estado de Mato Grosso. Campo Grande: EMBRAPA-CNPGC, 2000. 10 p. (EMBRAPACNPGC. Documentos, 98).

VALLE, C. B.; MOORE, K. J.; MILLER, D .A.. Cell wall composition and digestibility in five species of Brachiaria. Tropical Agriculture, Trinidad, v. 65, p. 337-340, 1988. 